\title{
Assessment of Biotic Integrity of the Coastal Freshwater Tidal Zone of a Temperate Estuary of South America through Multiple Indicators
}

\author{
N. Gómez • M. Licursi - D. E. Bauer • E. S. Ambrosio • \\ A. Rodrigues Capítulo
}

Received: 15 December 2011 / Revised: 5 June 2012 / Accepted: 11 June 2012 / Published online: 27 June 2012

(C) Coastal and Estuarine Research Federation 2012

\begin{abstract}
The aim of this study was to propose an index [Index of Biotic Integrity for the Río de la Plata (IBIRP)] formulated from a minimum of information-rich metrics related to biological integrity for evaluation of the coastal freshwater tidal zone of the Río de la Plata estuary. A total of 23 sites were selected along $170 \mathrm{~km}$ of shoreline $\left(34^{\circ} 27^{\prime} 10^{\prime \prime}\right.$ $\mathrm{S}, 58^{\circ} 30^{\prime} 21^{\prime \prime} \mathrm{W}$ and $35^{\circ} 23^{\prime} 28^{\prime \prime} \mathrm{S}, 57^{\circ} 08^{\prime} 50^{\prime \prime} \mathrm{W}$ ), being influenced by different land uses. We explored 36 biotic descriptors (designated candidate metrics), each of which is considered as an environmental indicator, and selected four metrics: two related to phytoplankton assemblage (planktonic cyanobacterial density and phytoplanktonic total density) and two linked to benthic assemblages, the diatoms (percent most tolerant taxa), and the invertebrates (percent Tanaidacea). The metrics that were chosen to integrate the IBIRP provide valuable information about the biotic integrity both in terms of time and space. The multimetric index can assume values between 0 (very bad status) and 10 (very good status). The IBIRP correlated significantly with the second $(p<0.001)$ and fourth $(p<0.01)$ factors of the factor analysis - those being related to variables indicative of eutrophication and organic pollution. This index constitutes an approach that is capable of reflecting the anthropogenic impacts produced along the coast of the Río de la Plata, with the inherent flexibility of being subject to modification and ultimate validation for estuaries of similar characteristics.
\end{abstract}

N. Gómez $(\triangle) \cdot$ M. Licursi • D. E. Bauer • E. S. Ambrosio •

A. Rodrigues Capítulo

Instituto de Limnología Dr. R. A. Ringuelet, CONICET (CCT La Plata)-UNLP (FCNyM),

Av. Calchaquí km 23.5,

1888, Florencio Varela, Buenos Aires, Argentina

e-mail: nora@ilpla.edu.ar
Keywords Estuary $\cdot$ Freshwater tidal zone $\cdot$ Biotic-integrity index $\cdot$ Phytoplankton $\cdot$ Benthic diatoms $\cdot$ Benthic invertebrates

\section{Introduction}

At least half the world's population resides in estuarine watersheds, and this proportion continues to grow. Human development in coastal river basins has greatly increased nutrient and sediment loads to downstream estuarine and coastal waters, resulting in a deterioration of water quality, a loss of fishery habitats and resources, and an overall decline in the ecologic and economic condition of the coastal zone (Adams 2005).

Cumulative deleterious effects on aquatic ecosystems, especially complex coastal ones, may be exerted through a cascade of interacting impacts on species at different levels of the food chain. Pollution, fishing pressure, habitat destruction, species introduction, and other anthropogenic stresses act simultaneously with internal and external physical, chemical, and biological forces (Jordan and Vaas 2000).

Recent marine legislation has arisen worldwide in order to protect and restore the ecologic quality or integrity within estuarine, coastal, and offshore systems (Borja et al. 2010). In the Southwestern Atlantic, several monitoring programs have been undertaken to evaluate the impact of different anthropogenic activities (Muniz et al. 2005). The tidal freshwater reaches of estuaries, however, have, in general, received little attention in ecological research, which may be partly due to their intermediate position between limnological and estuarine (marine) research (Schuchardt and Schirmer 1991; Gómez et al. 2004). Zones of tidal freshwater typically constitute a small proportion of the overall estuarine surface area, but studies have suggested that these 
reaches play an important role in the energy and biogeochemistry of the ecosystem (Lampman et al. 1999; Lionard et al. 2008). Those areas provide valuable goods and services, in terms of ecosystem trophic linkages and biodiversity. An example is the Río de la Plata - an extensive, shallow, and microtidal coastal plain estuary-that receives freshwater from South America's second largest watershed; it covering some 3.2 million $\mathrm{km}^{2}$. Within the Río de la Plata, the freshwater sector occupies some $13,000 \mathrm{~km}^{2}$, which portion affects approximately $180 \mathrm{~km}$ of shoreline on the coast of Argentina. This area provides the main drinking-water supply for the adjacent cities, and many consequential activities - related to industry, agriculture, cattle raising, navigation, tourism, and sports - are practiced throughout this area. In addition, the river itself constitutes a thoroughfare for access to ports upstream along the Paraná, the Paraguay, and the Uruguay rivers. The high degree of urbanization and industrialization that is concentrated in the coast of the freshwater tidal zone of the Río de la Plata estuary, particularly along the Argentine side, generates inputs of contaminants - including nutrients, organic matter, heavy metals, pesticides, hydrocarbons, suspended solids, and pathogenic agentsthat represent a menace both to the biota and to human health.

Despite the socioeconomic significance of the coastal zone of the Río de la Plata and the severity of the threats to which these natural surroundings have been exposed, no biotic indices are as yet available for a comprehensive monitoring and assessment of the ecological integrity of the coast. This shortcoming exists because South America in general still lacks biotic-integrity indices in order to enable the assessment of the freshwater areas of estuaries.

Organic-matter enrichment and eutrophication in combination with habitat destruction are the principal conditions that adversely affect the coast of the Río de la Plata estuary (FREPLATA 2005; Mianzan et al. 2001). An integral part of determining ecological integrity is the measurement of the biological integrity, typically emphasizing on the analysis of plankton, benthos, macroalgae, and fish (Borja and Dauer 2008). Karr and Dudley (1981) defined biological integrity as the capability of supporting and maintaining a balanced, integrated, and adaptive community of organisms that, in turn, have a species composition, diversity, and functional organization comparable to that of the natural habitat of the region.

The objective of this present investigation was to design an index of biotic integrity in order to assess the biologic status of the coastal freshwater tidal zone of the Río de la Plata, based on biotic descriptors related to the phytoplankton and benthos from the intertidal zone. Lacouture et al. (2006) point out that the phytoplankton is a first response assemblage of organisms directly affected by water-quality conditions and is therefore an important group for monitoring environmental changes. Since the coast of this estuary is rich in nutrients and is trophically based on phytoplankton as the initial link in the food chain (Nagy et al. 2002), we explored the metrics associated with those microproducers. Benthic diatoms and invertebrates were furthermore considered in view of their recognition in the literature as valuable ecologic indicators within freshwater and marine ecosystems (Barbour et al. 1999; Pearson and Rosenberg 1978; Dauer 1993; Snoeijs 1999), in addition to being well represented along the coast of this estuary (César et al. 2000; Gómez et al. 2009; Licursi et al. 2010; Rodrigues Capítulo et al. 1997). The aims of this study were therefore (1) to select biotic indicators suitable for a detection of ecologic degradation within the coast and (2) to combine these indicators into a multimetric index [the Index of Biotic Integrity for the Río de la Plata (IBIRP)] in order to contribute in the assessment of the ecological quality therein. This multimetric index serves to facilitate a description of estuarine environments in simple terms that can be readily understood and applied by nonscientists involved in the making, planning, and management decisions.

\section{Materials and Methods}

\section{Study Area}

According to its dynamics and geomorphologic characteristics, the Río de la Plata is divided into an inner and an outer region. The inner region is characterized by freshwater and the outer by brackish water. The isohaline of 0.5 practical salinity units (PSU) constitutes the boundary between the freshwater and the mixohaline zones. The present study was carried out in the inner region, along the Argentine coastline of the southern coastal fringe of the Río de la Plata estuary, between coordinates $34^{\circ} 27^{\prime} 10^{\prime \prime} \mathrm{S}, 58^{\circ} 30^{\prime} 21^{\prime \prime} \mathrm{W}$, and $35^{\circ} 23^{\prime} 28^{\prime \prime} \mathrm{S}, 57^{\circ} 08^{\prime} 50^{\prime \prime} \mathrm{W}$ (Fig. 1). Within this zone, freshwater predominates, and the tide is the only oceanic influence (Urien 1972). The tidal amplitude ranges from 30 to $100 \mathrm{~cm}$, and the cycle of the tidal shifts complete their passage through the whole estuary within about $12 \mathrm{~h}$. The dynamics of the Río de la Plata estuary are controlled mainly by the tides, the wind-driven waves, and the continental runoff. The discharge of freshwater (annual mean, $22,000 \mathrm{~m}^{3} \mathrm{~s}^{-1}$ ) from the Paraná and Uruguay rivers into the estuary exhibits a minimal seasonality, at a maximum mean of $26,000 \mathrm{~m}^{3} \mathrm{~s}^{-1}$ in winter and a minimum mean of $19,000 \mathrm{~m}^{3} \mathrm{~s}^{-1}$ in summer (Guerrero et al. 1997).

The southern coastal fringe of the Río de la Plata is characterized by a varied shoreline vegetation extending along the entire length of the coast and consisting in a spatial succession of reeds, scrubs, and hygrophilous woods constituting a transitional zone between the aquatic ecosystem 


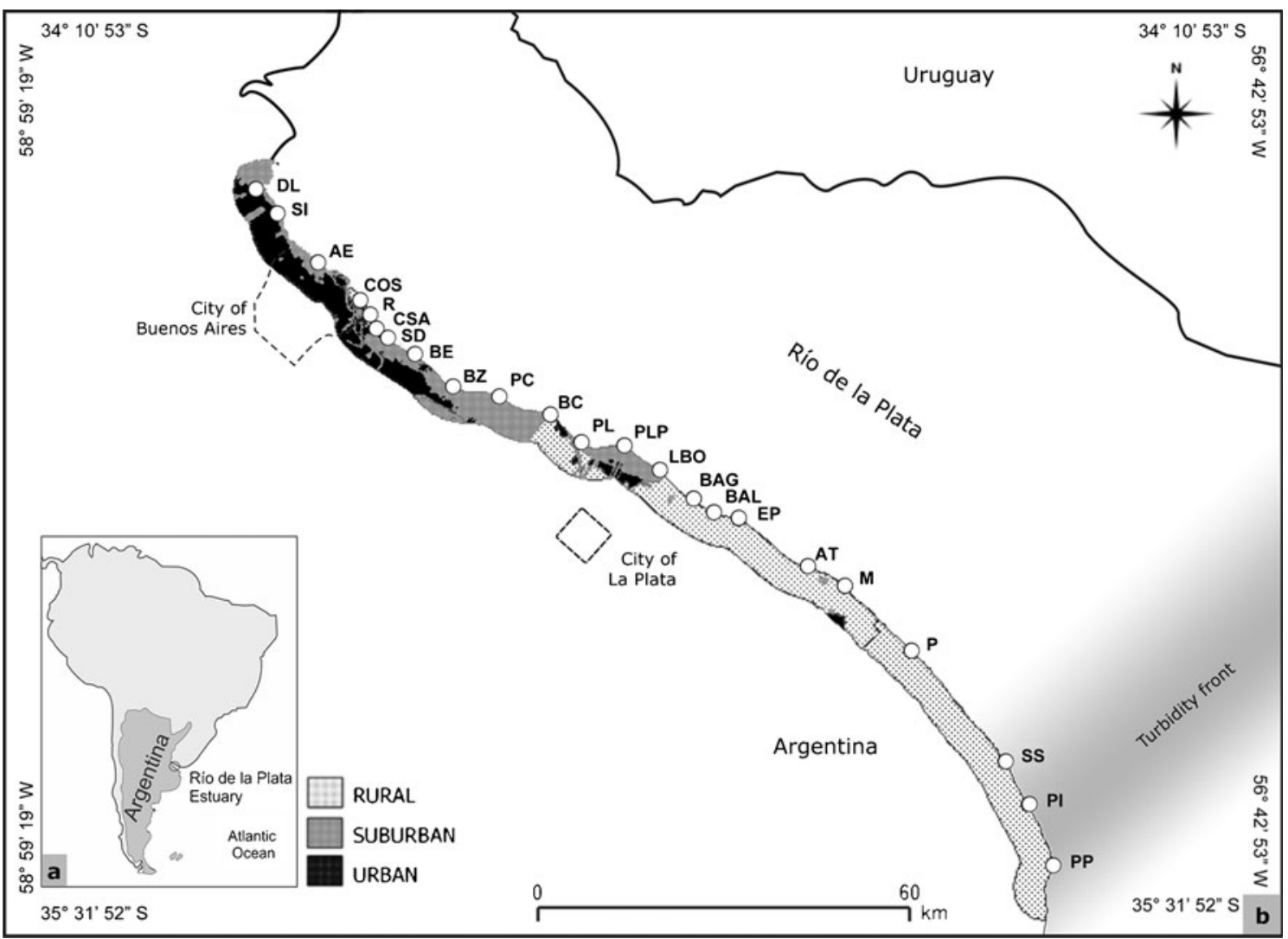

Fig. 1 a Location of the study area in South America (circle). b Map of the study area showing the sampling sites and the land uses in their surroundings

and the dry land. The anthropogenic interventions along the coast can alter or interrupt this distribution resulting in its fragmentation to the point of eliminating members of the native vegetation (Lahitte et al. 2004).

The sediments of the intertidal zone consist mainly of fine and very fine $(62.5-250 \mu \mathrm{m})$ sand (Gómez et al. 2009), a composition that can become modified through the accumulation of rubble as a consequence of anthropogenic interventions along the coast.

\section{Sampling Sites}

We considered a group of sites along the coast that represented differing environmental conditions. A total of 23 sampling sites were established along $170 \mathrm{~km}$ of shoreline, influenced by different land uses (Fig. 1). The northernmost sites (DL, SI, AE, COS, R, CSA, SD, and BE), through proximity, are exposed directly to the impact of Buenos Aires city, where navigational and port activities take place and where domestic and industrial effluents are discharged. Sites BZ and PC are located close to the sewage effluent of Buenos Aires city. In contrast, site BC is situated on the natural reserve Selva Marginal de Punta Lara, while site PL is exposed mainly to recreational and fishing activities; these two latter sites are influenced, however, by poor water quality caused by the human activities upstream. Sites PLP and BAG are located within the La Plata environs close to the port and the city's sewage effluent, respectively. The sites LBO, BAL, EP, AT, M, P, SS, PI, and PP are exposed to small-scale recreational, fishing, and rural activities (Fig. 1, Table 1). Table 2 summarizes the main physicochemical characteristics of the sampling sites.

\section{Data Collection}

The samples were collected in the intertidal zone at low tide and a water depth of $<1 \mathrm{~m}$. The data used for the development of the IBIRP included samples collected seasonally during 2005-2010. Samples from data sets corresponding to two different projects (PIP Res. 1556 and PICT 32077) were included. The field data and the samples for physicochemical and biological analyses were collected on each sampling event.

\section{Water Quality}

Dissolved oxygen (DO) concentration and biochemical oxygen demand $\left(\mathrm{BOD}_{5}\right)$ were investigated as indicators of 
Table 1 Code names for the sampling sites, and their locations along the coast of the Río de la Plata estuary

\begin{tabular}{lll}
\hline Site code & Site name & Coordinates \\
\hline DL & Desembocadura del río Luján & $34^{\circ} 27^{\prime} 10^{\prime \prime} \mathrm{S}, 58^{\circ} 30^{\prime} 21^{\prime \prime} \mathrm{W}$ \\
SI & San Isidro & $34^{\circ} 29^{\prime} 08^{\prime \prime} \mathrm{S}, 58^{\circ} 28^{\prime} 49^{\prime \prime} \mathrm{W}$ \\
AE & Aeroparque - Palermo & $34^{\circ} 32^{\prime} 57^{\prime \prime} \mathrm{S}, 58^{\circ} 25^{\prime} 35^{\prime \prime} \mathrm{W}$ \\
COS & Costanera Sur & $34^{\circ} 36^{\prime} 54^{\prime \prime} \mathrm{S}, 58^{\circ} 20^{\prime} 24^{\prime \prime} \mathrm{W}$ \\
R & Matanza -Riachuelo & $34^{\circ} 37^{\prime} 42^{\prime \prime} \mathrm{S}, 58^{\circ} 19^{\prime} 48^{\prime \prime} \mathrm{W}$ \\
CSA & Canal Sarandí & $34^{\circ} 39^{\prime} 31^{\prime \prime} \mathrm{S}, 58^{\circ} 18^{\prime} 59^{\prime \prime} \mathrm{W}$ \\
SD & Canal Santo Domingo & $34^{\circ} 40^{\prime} 01^{\prime \prime} \mathrm{S}, 58^{\circ} 18^{\prime} 04^{\prime \prime} \mathrm{W}$ \\
BE & Bernal & $34^{\circ} 41^{\prime} 30^{\prime \prime} \mathrm{S}, 58^{\circ} 15^{\prime} 14^{\prime \prime} \mathrm{W}$ \\
BZ & Berazategui & $34^{\circ} 44^{\prime} 38^{\prime \prime} \mathrm{S}, 58^{\circ} 10^{\prime} 42^{\prime \prime} \mathrm{W}$ \\
PC & Punta Colorada & $34^{\circ} 45^{\prime} 11^{\prime \prime} \mathrm{S}, 58^{\circ} 06^{\prime} 27^{\prime \prime} \mathrm{W}$ \\
BC & Boca Cerrada & $34^{\circ} 46^{\prime} 49^{\prime \prime} \mathrm{S}, 58^{\circ} 00^{\prime} 59^{\prime \prime} \mathrm{W}$ \\
PL & Punta Lara & $34^{\circ} 49^{\prime} 29^{\prime \prime} \mathrm{S}, 57^{\circ} 57^{\prime} 35^{\prime \prime} \mathrm{W}$ \\
PLP & Puerto La Plata & $34^{\circ} 50^{\prime} 01^{\prime \prime} \mathrm{S}, 57^{\circ} 52^{\prime} 50^{\prime \prime} \mathrm{W}$ \\
LBO & Los Borrachos & $34^{\circ} 51^{\prime} 17^{\prime \prime} \mathrm{S}, 57^{\circ} 50^{\prime} 21^{\prime \prime} \mathrm{W}$ \\
BAG & Bagliardi & $34^{\circ} 52^{\prime} 26^{\prime \prime} \mathrm{S}, 57^{\circ} 48^{\prime} 33^{\prime \prime} \mathrm{W}$ \\
BAL & Balandra & $34^{\circ} 55^{\prime} 44^{\prime \prime} \mathrm{S}, 57^{\circ} 42^{\prime} 56^{\prime \prime} \mathrm{W}$ \\
EP & El Pino & $35^{\circ} 16^{\circ} 45^{\prime \prime} \mathrm{S}, 57^{\circ} 13^{\prime} 18^{\prime \prime} \mathrm{S}, 57^{\circ} 08^{\prime} 50^{\prime \prime} \mathrm{W}$ \\
AT & Atalaya & $34^{\circ} 57^{\prime} 14^{\prime \prime} \mathrm{S}, 57^{\circ} 38^{\prime} 58^{\prime \prime} \mathrm{W}$ \\
M & Magdalena & $35^{\circ} 00^{\prime} 49^{\prime \prime} \mathrm{S}, 57^{\circ} 32^{\prime} 07^{\prime \prime} \mathrm{W}$ \\
P & Pearson & $35^{\circ} 01^{\prime} 50^{\prime \prime} \mathrm{S}, 57^{\circ} 29^{\prime} 38^{\prime \prime} \mathrm{W}$ \\
SS & Sarandí Sur & $35^{\circ} 07^{\prime} 27^{\prime \prime} \mathrm{S}, 57^{\circ} 22^{\prime} 53^{\prime \prime} \mathrm{W}$ \\
PI & Punta Indio & $35^{\circ} 12^{\prime} 57^{\prime \prime} \mathrm{S}, 57^{\circ} 17^{\prime} 07^{\prime \prime} \mathrm{W}$ \\
PP & Punta Piedras & \\
\hline
\end{tabular}

organic pollution. In addition, the concentrations of the dissolved nutrients, inorganic phosphate $\left(\mathrm{PO}_{4}{ }^{3-}-\mathrm{P}\right)$, and inorganic nitrogen (DIN: the sum of the nitrate, nitrite, and ammonium concentrations) were measured as indicators of eutrophication. For the analysis of $\mathrm{BOD}_{5}$, samples of $500 \mathrm{~mL}$ were collected, and for dissolved nutrients, samples of $250 \mathrm{~mL}$ of subsurface water were collected at each sampling site and filtered through Whatman $\mathrm{GF} / \mathrm{C}$ filters in situ before transport to the laboratory at $4{ }^{\circ} \mathrm{C}$. Inorganic phosphate, nitrite, and ammoniacal nitrogen were determined colorimetrically; nitrate was reduced to nitrite before colorimetric measurement (Mackereth et al. 1978). The $\mathrm{BOD}_{5}$ was measured after a 5-day incubation at $20{ }^{\circ} \mathrm{C}$ (Clesceri et al. 1998). DO (ISY 52 oxymeter), conductivity (Lutron CD-4303), turbidity (Turbidity Meter 800-ESD), and $\mathrm{pH}$ (Hanna HI 8633) were measured in situ.

\section{Biological Data}

Phytoplankton For quantitative analysis, three replicate subsurface water samples $(125 \mathrm{~mL})$ were collected at each sampling site and preserved with formalin [final concentration, $2 \%(v / v)]$. Phytoplankton were counted according to Lund et al. (1958) under an inverted microscope at $\times 600$. Water samples (250-1,000 $\mathrm{mL})$ for determination of chlorophyll $a$ were filtered immediately with Whatman $\mathrm{GF} / \mathrm{C}$ filters and were then transported to the laboratory in the dark at $4{ }^{\circ} \mathrm{C}$. Chlorophyll $a$ was determined spectrophotometrically using $90 \%(v / v)$ aqueous acetone after Clesceri et al. (1998).

Benthic Diatoms At each site, five subsamples samples of the surface layer $(0.5 \mathrm{~cm})$ of the sediments were collected with a core (area $3.14 \mathrm{~cm}^{2}$ ), pooled, and preserved with $4 \%$ $(v / v)$ formalin. Diatoms were cleaned with $\mathrm{H}_{2} \mathrm{O}_{2}$, washed thoroughly with distilled water, and mounted on microscope slides with Naphrax ${ }^{\circledR}$. In order to determine the relative abundance of the various taxa in each sample, a total of 400 valves were examined under an Olympus BX 51 microscope at a magnification of $\times 1,000$ with phase contrast and Normarski-DIC optics.

Invertebrates Three replicate sediment samples were taken at each sampling site (with an Ekman grab covering an area of $100 \mathrm{~cm}^{2}$ ). In the laboratory, the benthic samples were washed on a $250-\mu \mathrm{m}$-mesh sieve and stained with erythrosin B. The invertebrates were sorted out from the particulate sediments under a stereoscopic microscope.

Biotic Indices and Species Tolerance The species diversity was calculated by the Shannon-Wiener index $\left[H^{\prime}=\sum\left(\mathrm{P}_{i} \times\right.\right.$ $\left.\log _{2} P_{i}\right)$, where $P_{i}=n_{i} / N$; Shannon and Weaver 1949] and the evenness by the Pielou index $\left(J=H^{\prime} / \log _{2} S\right.$, where $S$ is species richness; Pielou 1969).

The classification of the diatom species as sensitive, tolerant, or most tolerant was done according to Licursi et al. (2010) and of the invertebrates as indicated in Merrit and Cummins (1996) and Rodrigues Capítulo et al. (2001).

\section{Statistical Analysis}

The main environmental gradients within the study area were explored by the principal components analysis (PCA) based on standardized physicochemical variables. The data were standardized to insure that all variables have an equal weight in the analysis (Pla 1986). The principal components with eigenvalues greater than or close to unity were retained. For the interpretation of the factors that were considered relevant, the PCA was followed by a factor analysis (FA) including a varimax-normalized rotation to reveal variables that had the strongest correlations with the retained factors (Singh et al. 2004).

Discriminant analyses (DAs) were used to classify sites in relation to the degree of water-quality impairment (Sloane and Morgan 1996). This analysis has been identified as an acceptable statistical method for the development of indices of biotic integrity and can be used to identify variables that can 
Table 2 Physicochemical characteristics of each sampling site (mean \pm standard deviation)

\begin{tabular}{|c|c|c|c|c|c|c|c|}
\hline Site & $\mathrm{pH}$ & Turbidity (NTU) & Conductivity $\left(\mu \mathrm{S} \mathrm{cm}^{-1}\right)$ & $\mathrm{DO}\left(\mathrm{mg} \mathrm{L}^{-1}\right)$ & $\mathrm{DIN}\left(\mathrm{mg} \mathrm{L}^{-1}\right)$ & $\mathrm{PO}_{4}{ }^{3-} \mathrm{P}\left(\mathrm{mg} \mathrm{L}^{-1}\right)$ & $\mathrm{BOD}_{5}\left(\mathrm{mg} \mathrm{L}^{-1}\right)$ \\
\hline DL & $7.8 \pm 0.9$ & $228 \pm 214$ & $533 \pm 759$ & $8.0 \pm 2.1$ & $0.98 \pm 0.42$ & $0.25 \pm 0.30$ & $2.6 \pm 1.5$ \\
\hline SI & $7.6 \pm 0.4$ & $114 \pm 146$ & $314 \pm 649$ & $7.2 \pm 0.7$ & $1.46 \pm 0.25$ & $0.24 \pm 0.10$ & $3.8 \pm 2.2$ \\
\hline $\mathrm{AE}$ & $7.7 \pm 0.6$ & $206 \pm 187$ & $618 \pm 954$ & $6.4 \pm 1.2$ & $1.24 \pm 0.46$ & $0.11 \pm 0.04$ & $3.4 \pm 1.8$ \\
\hline $\operatorname{COS}$ & $8.0 \pm 0.5$ & $420 \pm 91$ & $346 \pm 235$ & $7.4 \pm 0.9$ & $1.72 \pm 0.39$ & $0.12 \pm 0.13$ & $14.7 \pm 1.3$ \\
\hline $\mathrm{R}$ & $7.0 \pm 0.3$ & $221 \pm 52$ & $562 \pm 187$ & $2.0 \pm 0.3$ & $2.67 \pm 0.23$ & $0.32 \pm 0.11$ & $15.0 \pm 0.9$ \\
\hline CSA & $7.9 \pm 0.7$ & $213 \pm 64$ & $707 \pm 265$ & $5.6 \pm 1.4$ & $2.76 \pm 0.28$ & $0.40 \pm 0.18$ & $15.0 \pm 1.4$ \\
\hline $\mathrm{SD}$ & $7.9 \pm 0.3$ & $189 \pm 164$ & $1002 \pm 501$ & $2.6 \pm 2.3$ & $2.36 \pm 1.22$ & $1.47 \pm 1.12$ & $12.7 \pm 1.2$ \\
\hline $\mathrm{BE}$ & $8.2 \pm 0.8$ & $190 \pm 49$ & $561 \pm 270$ & $8.6 \pm 3.3$ & $1.87 \pm 0.61$ & $0.49 \pm 0.51$ & $8.5 \pm 4.4$ \\
\hline $\mathrm{BZ}$ & $8.4 \pm 0.4$ & $196 \pm 193$ & $467 \pm 92$ & $9.1 \pm 2.7$ & $1.91 \pm 0.48$ & $0.32 \pm 0.10$ & $6.6 \pm 4.0$ \\
\hline $\mathrm{PC}$ & $8.3 \pm 1.0$ & $160 \pm 140$ & $427 \pm 98$ & $10.4 \pm 1.1$ & $0.55 \pm 0.50$ & $0.24 \pm 0.08$ & $4.0 \pm 0.1$ \\
\hline $\mathrm{BC}$ & $8.5 \pm 0.7$ & $120 \pm 95$ & $347 \pm 72$ & $9.2 \pm 1.6$ & $1.17 \pm 0.35$ & $0.23 \pm 0.07$ & $5.3 \pm 4.3$ \\
\hline PL & $8.5 \pm 0.7$ & $139 \pm 113$ & $323 \pm 110$ & $10.3 \pm 3.0$ & $1.34 \pm 0.41$ & $0.30 \pm 0.18$ & $7.5 \pm 5.0$ \\
\hline PLP & $8.0 \pm 0.5$ & $229 \pm 98$ & $429 \pm 95$ & $6.9 \pm 0.4$ & $1.52 \pm 0.38$ & $0.21 \pm 0.21$ & $2.4 \pm 1.8$ \\
\hline LBO & $8.3 \pm 0.4$ & $299 \pm 118$ & $550 \pm 89$ & $9.5 \pm 0.5$ & $2.00 \pm 0.48$ & $0.34 \pm 0.03$ & $5.2 \pm 1.1$ \\
\hline BAG & $7.8 \pm 0.2$ & $79 \pm 68$ & $574 \pm 241$ & $7.7 \pm 1.9$ & $1.03 \pm 0.82$ & $0.65 \pm 0.44$ & $16.2 \pm 9.0$ \\
\hline BAL & $8.5 \pm 0.6$ & $196 \pm 143$ & $410 \pm 146$ & $9.3 \pm 1.5$ & $0.45 \pm 0.39$ & $0.15 \pm 0.06$ & $6.7 \pm 2.2$ \\
\hline EP & $8.4 \pm 0.3$ & $300 \pm 209$ & $564 \pm 257$ & $11.1 \pm 0.8$ & $0.19 \pm 0.35$ & $0.13 \pm 0.08$ & $3.2 \pm 2.7$ \\
\hline AT & $8.2 \pm 0.2$ & $246 \pm 328$ & $732 \pm 452$ & $8.6 \pm 0.5$ & $0.72 \pm 0.33$ & $0.12 \pm 0.05$ & $7.9 \pm 3.8$ \\
\hline M & $8.4 \pm 0.7$ & $779 \pm 266$ & $1299 \pm 1070$ & $8.8 \pm 0.9$ & $0.58 \pm 0.49$ & $0.14 \pm 0.07$ & $8.5 \pm 7.2$ \\
\hline $\mathrm{P}$ & $8.6 \pm 0.5$ & $630 \pm 252$ & $1858 \pm 1430$ & $9.1 \pm 0.7$ & $0.54 \pm 0.57$ & $0.14 \pm 0.07$ & $5.2 \pm 4.8$ \\
\hline SS & $8.0 \pm 0.4$ & $998 \pm 276$ & $5393 \pm 2190$ & $8.5 \pm 0.9$ & $0.23 \pm 0.27$ & $0.08 \pm 0.06$ & $4.3 \pm 3.1$ \\
\hline PI & $8.2 \pm 0.5$ & $490 \pm 366$ & $5313 \pm 4573$ & $8.4 \pm 1.0$ & $0.38 \pm 0.30$ & $0.14 \pm 0.08$ & $7.0 \pm 6.7$ \\
\hline PP & $8.4 \pm 0.9$ & $772 \pm 291$ & $6452 \pm 4245$ & $8.9 \pm 0.7$ & $0.43 \pm 0.33$ & $0.11 \pm 0.05$ & $6.4 \pm 5.3$ \\
\hline
\end{tabular}

For the sampling site abbreviations, see Table 1

$D O$ dissolved oxygen, $D I N$ sum of the nitrate, nitrite, and ammonium concentrations, $B O D_{5} 5$ days biochemical oxygen demand $(n=129)$

discriminate between levels of degradation (USEPA 1998). Predictor variables selected for this analysis were DIN, $\mathrm{PO}_{4}{ }^{3-}-$ $\mathrm{P}, \mathrm{BOD}_{5}$, and DO. Nitrogen and phosphorus are indicators of estuarine health because of their potential impact on the eutrophication process; $\mathrm{BOD}_{5}$ is a good indicator of the degree of organic pollution, and finally, the DO levels are crucial for most estuarine organisms (USEPA 2006).

In the metric-selection process, and in the discrimination between the least and most impaired sites, either the Student $t$ test or the Mann-Whitney test were used, depending on the normal or nonnormal distribution of the data, respectively (Zar 1996).

Spearman's rank-order correlation was used to establish the relationships between the metrics and to relate the final index scores to the FA factors.

\section{Construction of the IBIRP}

\section{Site Classification}

In order to identify the least and most impaired sites, an a priori classification was performed scoring the cases as having either good, moderate, or bad water quality. For this purpose, an individual value for each case was assigned-1, 3 , or 5 -taking into account the 25th and 75th percentiles of the full dataset for $\mathrm{DO}, \mathrm{DIN}, \mathrm{PO}_{4}{ }^{3-}-\mathrm{P}$, and $\mathrm{BOD}_{5}$ (Table 3). These values were then summed to form water-quality classes that fluctuated between 4 and 20. Values of 16,18 , or 20 were classified as good water quality; values of 10,12 , or 14 were classified as moderate water quality; and values of 4,6 , or 8 were classified as bad water quality (Kane et al. 2009). Afterwards, a DA was performed based on the aforementioned water-quality variables, and the resulting a posteriori classification was adopted in order to define the least and most impaired sites.

Table 3 Assigned individual value in relation to the ranges of the selected chemical variables related to water quality

\begin{tabular}{lllcc}
\hline $\begin{array}{l}\text { Assigned } \\
\text { individual value }\end{array}$ & $\begin{array}{l}\mathrm{DO} \\
\left(\mathrm{mg} \mathrm{L}^{-1}\right)\end{array}$ & $\begin{array}{l}\mathrm{DIN} \\
\left(\mathrm{mg} \mathrm{L}^{-1}\right)\end{array}$ & $\begin{array}{l}\mathrm{PO}_{4}{ }^{3-}-\mathrm{P} \\
\left(\mathrm{mg} \mathrm{L}^{-1}\right)\end{array}$ & $\begin{array}{l}\mathrm{BOD}_{5} \\
\left(\mathrm{mg} \mathrm{L}^{-1}\right)\end{array}$ \\
\hline 5 & $>8.2$ & $<0.55$ & $<0.13$ & $<3$ \\
3 & $8.2-5$ & $0.55-1.64$ & $0.13-0.32$ & $3-10$ \\
1 & $<5$ & $>1.64$ & $>0.32$ & $>10$ \\
\hline
\end{tabular}




\section{Metric Selection}

A "metric" is defined as a measurable part or process of a biological system empirically shown to change in value along a gradient of human influence (Karr and Chu 1999).

Different candidate metrics, corresponding to any of the following categories, i.e., abundance $(A)$, diversity and richness $(D)$, tolerance to pollution $(T)$, or composition $(C)$
(Barbour et al. 1999; Borja et al. 2004, 2007), were tested for the development of the IBIRP (Table 4).

We followed the steps in metric selection proposed by Stoddard et al. (2008) and accordingly eliminated metrics that had very small ranges or when greater than one third of the samples had values $=0$. The reproducibility of the metrics was analyzed with a variant of the signal/noise ratio ( $\mathrm{S} / \mathrm{N}$; Kaufmann et al. 1999). $\mathrm{S} / \mathrm{N}$ is the ratio of the variance
Table 4 List of the candidate metrics evaluated for the construction of the IBIRP
The metric categories are shown (A: abundance; D: diversity and richness; T: tolerance to pollution; C: composition), as well as the results of applied criteria of metric range, reproducibility, and responsiveness for the selection of the metrics. The selected metrics are in italic

$(+)$ passed

${ }^{*} p<0.001$

\begin{tabular}{|c|c|c|c|c|}
\hline Candidate metrics & Category & Metric range & $\begin{array}{l}\text { Reproducibility } \\
\text { (signal/noise) }\end{array}$ & $\begin{array}{l}\text { Responsiveness ( } t \text { test } / \\
\text { Mann-Whitney test) }\end{array}$ \\
\hline \multicolumn{5}{|l|}{ Phytoplankton } \\
\hline Chlorophyll $a$ & A & + & & \\
\hline Total density & $A$ & + & + & $*$ \\
\hline Cyanobacterial density & $A$ & + & + & $*$ \\
\hline Species number & $\mathrm{D}$ & + & & $*$ \\
\hline Diversity index $\left(H^{\prime}\right)$ & $\mathrm{D}$ & + & & \\
\hline Evenness & $\mathrm{D}$ & + & & \\
\hline$\%$ Most tolerant algae & $\mathrm{T}$ & + & + & \\
\hline$\%$ Sensitive algae & $\mathrm{T}$ & & + & \\
\hline \% Cyanobacteria & $\mathrm{C}$ & + & & \\
\hline \% Euglenophyta & $\mathrm{C}$ & & + & $*$ \\
\hline \% Pyrrophyta & $\mathrm{C}$ & & + & \\
\hline$\%$ Chlorophyta & $\mathrm{C}$ & + & + & \\
\hline$\%$ Bacillariophyta & $\mathrm{C}$ & + & & \\
\hline \multicolumn{5}{|l|}{ Benthic diatoms } \\
\hline Species number & $\mathrm{D}$ & + & & \\
\hline Diversity index $\left(H^{\prime}\right)$ & $\mathrm{D}$ & + & + & \\
\hline Evenness & $\mathrm{D}$ & + & & \\
\hline$\%$ Most tolerant & $T$ & + & + & $*$ \\
\hline$\%$ Sensitive & $\mathrm{T}$ & + & + & \\
\hline$\%$ Aberrant forms & $\mathrm{T}$ & & + & \\
\hline \multicolumn{5}{|l|}{ Benthic invertebrates } \\
\hline Total density & A & + & & \\
\hline Species number & $\mathrm{D}$ & + & & \\
\hline Diversity index (H') & $\mathrm{D}$ & + & & \\
\hline Evenness & $\mathrm{D}$ & + & & \\
\hline$\%$ Most tolerant & $\mathrm{T}$ & + & & \\
\hline$\%$ Sensitive & $\mathrm{T}$ & & + & \\
\hline$\%$ Oligochaeta & $\mathrm{C}$ & + & & \\
\hline$\%$ Bivalvia & $\mathrm{C}$ & + & + & \\
\hline$\%$ Nematoda & $\mathrm{C}$ & + & & \\
\hline$\%$ Tardigrada & $\mathrm{C}$ & & + & \\
\hline$\%$ Gastropoda & $\mathrm{C}$ & + & + & \\
\hline$\%$ Chironomidae & $\mathrm{C}$ & & + & \\
\hline$\%$ Hirudinea & $\mathrm{C}$ & & + & \\
\hline \% Isopoda & $\mathrm{C}$ & & + & \\
\hline$\%$ Amphipoda & $\mathrm{C}$ & & & \\
\hline$\%$ Tanaidacea & $C$ & + & + & $*$ \\
\hline$\%$ Cumacea & $\mathrm{C}$ & & + & \\
\hline
\end{tabular}


among all sites (i.e., the signal) to the variance of repeated visits to the same site (i.e., the noise). In our study, the phytoplankton and benthic-diatom metrics with $\mathrm{S} / \mathrm{N}$ values of $<1.5$ were discarded; likewise, the invertebrateassemblage metrics with a ratio of $<2$ were discarded (Stoddard et al. 2008). The ability of the metrics to differentiate between the least and the most impaired sites (i.e., a measure of environmental responsiveness) was analyzed by comparing the metrics values through the $t$ test or the Mann-Whitney test; accordingly, those metrics that showed statistically significant differences $(p<0.001)$ were selected.

The metrics selected were not redundant, thus showing Spearman's correlations of $<0.80$ (Hering et al. 2006).

The metrics that passed all the selection steps were chosen to integrate the IBIRP. The four selected metrics (Table 4) were the following: the planktonic cyanobacterial density (PCD), the phytoplankton total density (PTD), the percentage of most tolerant diatoms (\%MTD) (Table 5), and the percentage of Tanaidacea $(\% \mathrm{~T})$.

\section{Scoring of the Selected Metrics}

We scored the selected metrics using continuous scoring $(0-10)$ to avoid the subjective nature inherent in discrete scoring (Böhmer et al. 2004; Hering et al. 2006; Stoddard et al. 2008). In order to fix the ceiling of the metrics, we used the 5th or 95th (depending on whether the metric increased or decreased with impairment) of the distribution of values of the least impaired sites. In order to fix the floor of the metrics we used the 5th or 95th (depending on whether the metric decreased or increased with impairment) of the distribution of values of the total data set (Table 6).

Table 5 Most tolerant diatoms found in the coast of the Río de la Plata (Licursi et al. 2010)

\footnotetext{
Diadesmis contenta (Grunow) Mann

Frustrulia vulgaris (Thwaites) De Toni

Luticola goeppertiana (Bleisch) Mann

L. ventricosa (Grunow) Mann

Mayamaea atomus (Kützing) Lange-Bertalot

Navicula monoculata Hustedt

N. schroeteri Meister

Neidium iridis (Ehrenberg) Cleve

Nitzschia brevissima Grunow

N. claussi Hantzsch

N. palea (Kützing) Smith

N. sigma (Kützing) Smith

N. umbonata (Ehrenberg) Lange-Bertalot

Placoneis placentula (Ehrenberg) Heinzerling

Sellaphora pupula (Kützing) Mereschkowksy
}

Table 6 Threshold values for the selected metrics

\begin{tabular}{lrr}
\hline & Ceiling & \multicolumn{1}{c}{ Floor } \\
\hline Planktonic cyanobacterial density $\left(\right.$ cell mL $\left.\mathrm{mL}^{-1}\right)$ & 0 & 25,000 \\
Phytoplanktonic total density $\left(\right.$ cell $\left.\mathrm{mL}^{-1}\right)$ & 30 & 80,000 \\
\% Most tolerant diatoms & 1 & 40 \\
\% Tanaidacea & 25 & 0 \\
\hline
\end{tabular}

Ceiling: 5th (planktonic cyanobacterial density, phytoplanktonic total density, $\%$ most tolerant diatoms) or 95 th ( $\%$ Tanaidacea) values of the least impaired sites (see text). Floor: 5th (\% Tanaidacea) or 95 th (planktonic cyanobacterial density, phytoplanktonic total density, \% most tolerant diatoms) values of all data

The scaling was done with the following formula, modified from Böhmer et al. (2004):

Scored metric $=($ value for test site - floor $) /($ ceiling - floor $) \times 10$

Those values $>10$ were set as 10 and values $<0$ were set as 0 .

This formula works for metrics either decreasing or increasing with increasing impairment.

\section{IBIRP Expression}

Finally, the scores of the selected metrics were combined into a multimetric index (IBIRP) by calculating the mean of their $0-10$ scores:

$\operatorname{IBIRP}=(\mathrm{PCD}+\mathrm{PTD}+\% \mathrm{MTD}+\% \mathrm{~T}) / 4$

The IBIRP scores vary between 0 (very bad status) and 10 (very good status). We established five classes of biological status associated with different degrees of environmental impairment (Table 7).

\section{Results and Discussion}

According to the multivariate analysis, the four FA factors retained explained $79.1 \%$ of the total variance (Fig. 2). The environmental variables that had strong loadings (factor loading $>0.8$ ) in those factors enabled a characterization of the natural dynamics of the estuary and the impact caused by human activities. The first and third factors accounted for $42.6 \%$ and had strong loadings of turbidity, conductivity, and $\mathrm{pH}$ - those variables being linked to the natural dynamics of the estuary (Fig. 2a, c). The second and fourth factors, which explained $36.6 \%$, had strong loadings of the DIN, $\mathrm{PO}_{4}{ }^{3-}-\mathrm{P}$, and $\mathrm{BOD}_{5}$ concentrations and reflected the impact of pollution within the study area (Fig. 2b, d).

DA based on the chemical characteristics mainly related to water quality assigned $80 \%$ of the cases correctly, with $25.2 \%$ corresponding to good and $8.1 \%$ to bad water 
Table 7 IBIRP class boundaries, their color codes for graphical representation, and characterization of the categories

\begin{tabular}{|c|c|c|c|}
\hline IBIRP value & Status & Colour code & Characterization \\
\hline$<2$ & Very bad & Red & $\begin{array}{l}\text { Very high pollution, high concentrations of organic } \\
\text { matter and nutrients, presence of industrial wastes; } \\
\text { high algal growth and very high risk of local } \\
\text { development of cyanobacterial blooms }\end{array}$ \\
\hline$\geq 2-4$ & $\mathrm{Bad}$ & Orange & $\begin{array}{l}\text { Heavily polluted, partially degraded organic matter, } \\
\text { high concentrations of nutrients that promote algal } \\
\text { growth and high risk of local development of } \\
\text { cyanobacterial blooms }\end{array}$ \\
\hline$\geq 4-6$ & Moderate & Yellow & $\begin{array}{l}\text { Moderately polluted, moderate nutrient concentrations, } \\
\text { risk of local development of potentially toxic blooms }\end{array}$ \\
\hline$\geq 6-8$ & Good & Green & $\begin{array}{l}\text { Sligthly polluted, low risk of local development of } \\
\text { potentially toxic blooms }\end{array}$ \\
\hline$\geq 8-10$ & Very good & Blue & $\begin{array}{l}\text { Low concentrations of organic matter and nutrients, } \\
\text { and scarce algal growth }\end{array}$ \\
\hline
\end{tabular}

quality and the reminder to moderate water quality. This analysis thus allowed a differentiation between the least and the most impaired sites (Fig. 3).

The methodology employed enabled us to select biological indicators related to the water column (i.e., the planktonic cyanobacterial density and the phytoplankton total density) and to the sediments (i.e., the percentage of most tolerant diatoms and the percentage of Tanaidacea) of the intertidal zone, which integrate information relevant for assessing the biotic integrity of the freshwater zone of the Río de la Plata estuary. According to the IBIRP values obtained for the 129 sites analyzed, $20.9 \%$ corresponded to very good status, $58.9 \%$ to good status, $13.2 \%$ to moderate status, 3.9 and $3.1 \%$ to bad and very bad status, respectively (Fig. 4). The index was able to differentiate significantly $(p<0.001)$ between the least and the most
Fig. 2 Factor loadings for the first four rotated factors with their percentage of explained variance. TURB turbidity, COND conductivity, $D O$ dissolved oxygen, DIN sum of the nitrate, nitrite, and ammonium concentrations, PO4 $\mathrm{PO}_{4}{ }^{3-}-\mathrm{P}$ concentration, $B O D 5$ days biochemical oxygen demand
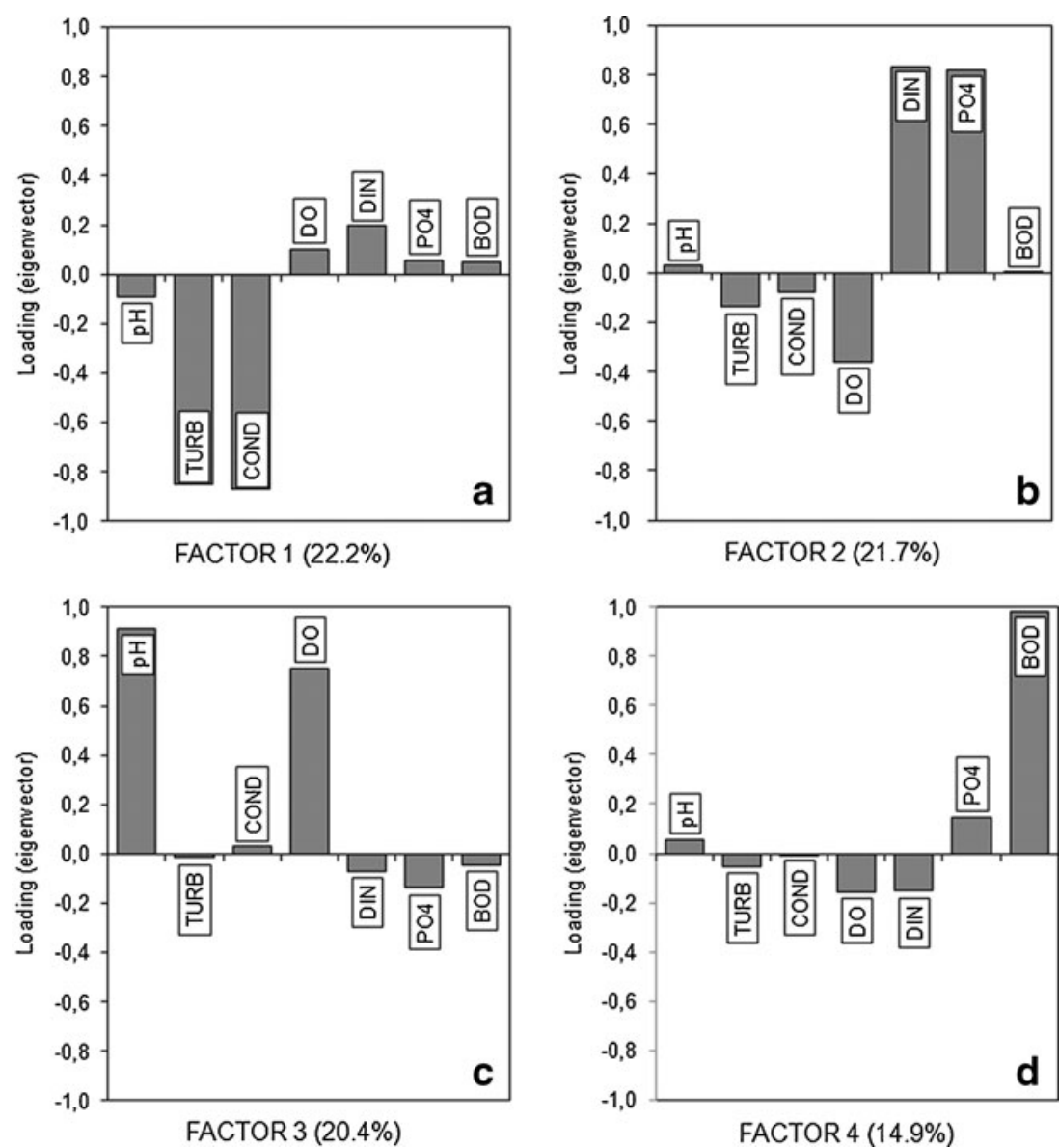

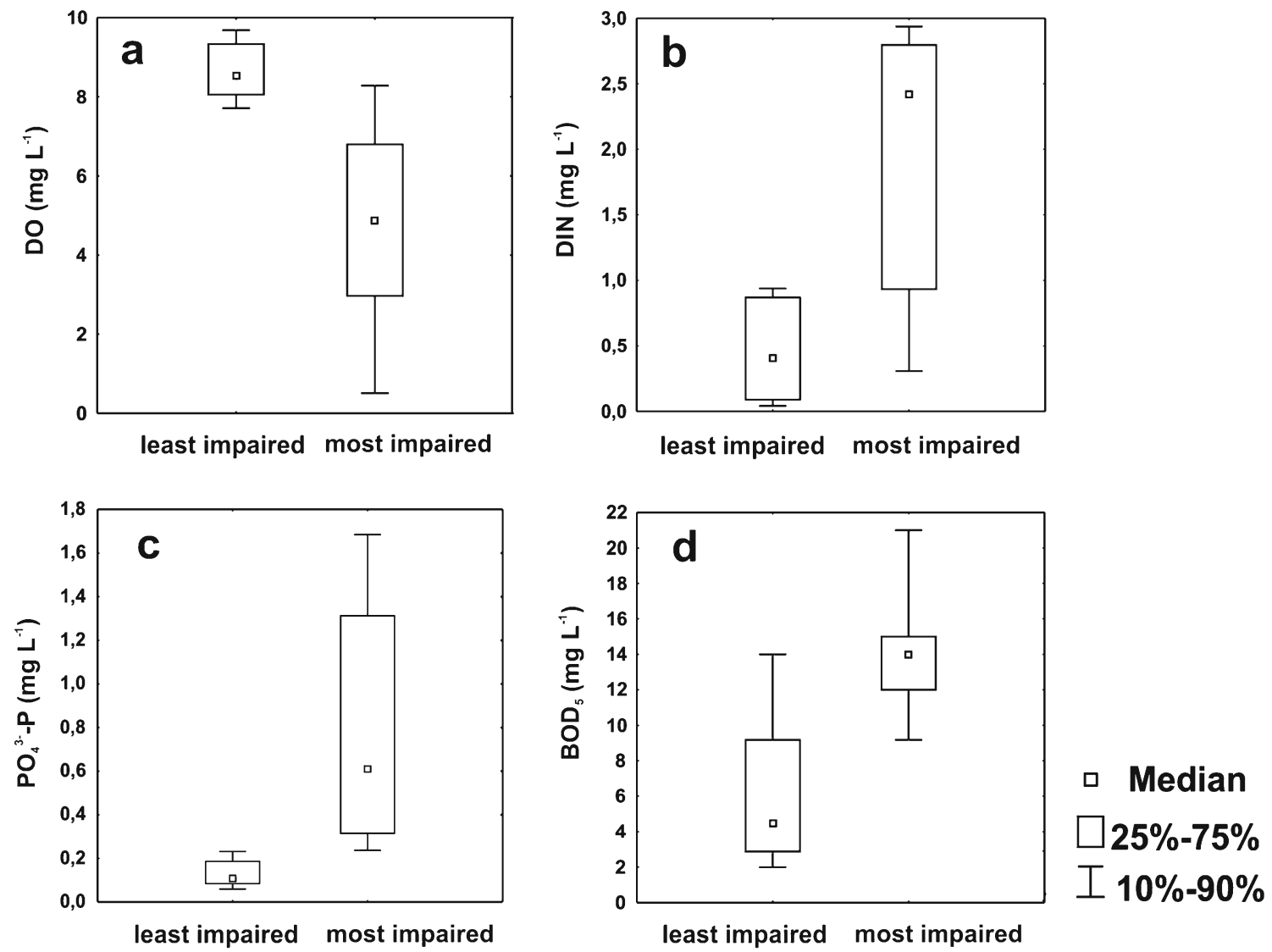

Fig. 3 Boxplots of the environmental variables related to the water quality in the least $(n=22)$ and most impaired $(n=15)$ sites: a dissolved oxygen, b dissolved inorganic nitrogen, $\mathbf{c}$ inorganic phosphate, and $\mathbf{d}$ biochemical oxygen demand

impaired status among the sites studied (Fig. 5). Furthermore, this index correlated significantly with the second $(p<0.001)$ and fourth $(p<0.01)$ factors of the FA-those being related to variables indicative of eutrophication and organic pollution.

Despite the marked physical-chemical variability observed within the study area, the IBIRP achieved significant

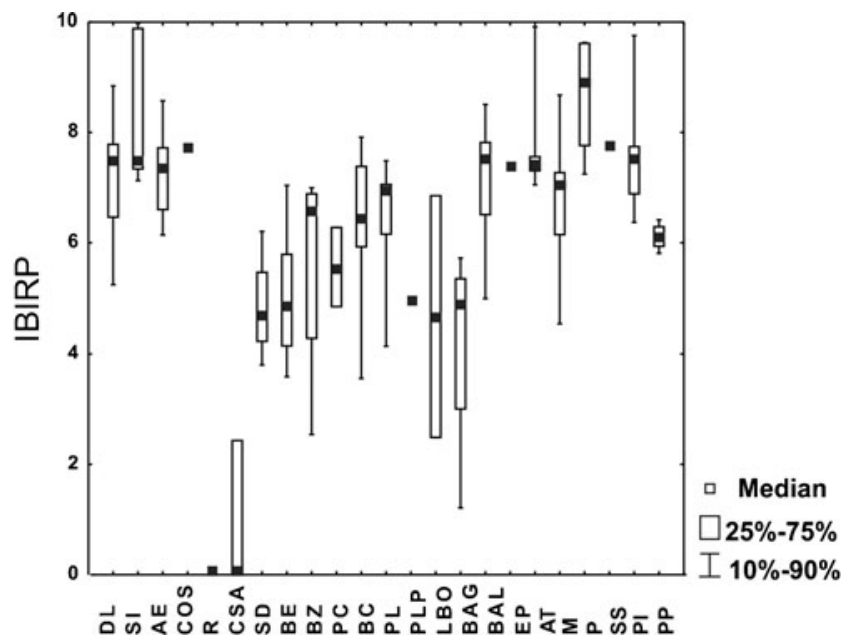

Fig. 4 Boxplots of the IBIRP values obtained for the sampled sites correlations with the gradient of human impact along the coast. The methodology employed for the selection of metrics identified four biotic metrics related to the taxonomic composition, abundance, and tolerance to pollution that were responsive to the different degrees of environmental deterioration detected at the sites along the coast. Accordingly, the increase in phytoplankton density was linked to nutrient enrichment and consequently to eutrophication

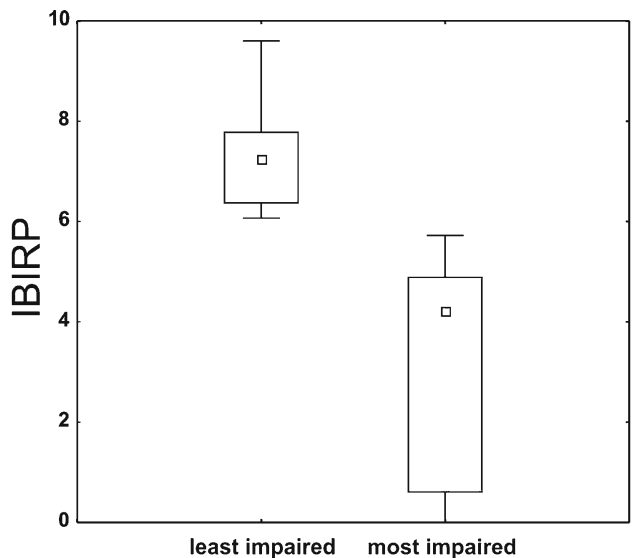

Median $25 \%-75 \%$ 工 $10 \%-90 \%$

Fig. 5 Boxplots of the IBIRP values in the least $(n=22)$ and most impaired $(n=15)$ sites in the study area 
(Margalef 1983; Bricker et al. 1999). Eutrophication, for its part, has adverse effects - including losses in biodiversity, ecosystem degradation, harmful algal blooms, and oxygen deficiency - that, in turn, alter coastal productivity, nutrient cycling, water quality, and the overall health of the ecosystem (Ferreira et al. 2011). According to Paerl et al. (2003) in the southeastern riverine-estuarine systems of the USA, a combination of reduced flushing and high nutrient inputs promoted conditions suitable for the expansion of opportunistic phytoplankton species, particularly nuisance cyanobacteria. Such cyanobacterial blooms can adversely affect both aquatic communities and human health (Codd et al. 2005). In the freshwater tidal zone of the Río de la Plata, the development of cyanobacteria, especially represented by species of Microcystis, is a recurrent phenomenon and a risk to the uses and services offered by the coast (FREPLATA 2005; Gómez et al. 2004; Gómez and Bauer 2000). From the standpoint of the residence time of water in the Río de la Plata (46 days; FREPLATA 2005) and the occurrence of previous developments of cyanotoxin-producing species within the study area (FREPLATA 2005; De León and Yunes 2001), the metric related to cyanobacterial abundance is seen to be highly relevant to the diagnosis of coastal environmental health.

Since diatoms are sensitive sensors for use in the identification of changes related to water chemistry (Descy and Coste 1990; Gómez and Licursi 2001), the inclusion of those algae in the IBIRP contributed to the environmental diagnosis. The information provided by the metric reflecting the percentage of diatoms most tolerant to pollution indicated the degree of eutrophication and organic enrichment occurring in the sediments, as the species represented by this metric tolerate high concentrations of phosphate $\left(>0.4 \mathrm{mg} \mathrm{L}^{-1}\right)$ and DIN $\left(>2.9 \mathrm{mg} \mathrm{L}^{-1}\right)$ and a high $\mathrm{BOD}_{5}$ (>12 $\mathrm{mg} \mathrm{L}^{-1}$; Licursi et al. 2010).

The metric involving the percentage of Tanaidaceae consists in species susceptible to environmental changes (Guidetti et al. 2000; Guerra-García and García-Gómez 2004) and thus provides information on the quality of the coastal habitat. In the Río de la Plata estuary Kalliapseudes schubarti and Sinelobus stanfordi are the native tanaidaceans present in the benthic communities (Taberner 1983; César et al. 2000). Recent research in the study area (Ferreira et al. 2008) has revealed that the population of $S$. stanfordi - the most abundant taxon within the coast-is particularly sensitive to anthropogenic stressors, such as high levels of organic matter along with other pollutantssuch as heavy metals, pesticides, and polychlorobiphenyls - accumulated in the sediments of the study area (AAAGOSBA-ILPLA-SHN 1997; FREPLATA 2005).

In the IBIRP, the combination of metrics both related to a drifter community (e.g., the phytoplankton) and linked to sedentary living (e.g., the diatoms and benthic invertebrates) facilitates the integration of different spatial scales. Furthermore, the metrics selected include organisms with different generation times (i.e., days for the algae up to months for the tanaidaceans), thus encompassing different time scales. Therefore, because of the range of both of these scales, the IBIRP is capable of gathering the information necessary for a holistic evaluation of biotic integrity of the sampling sites being monitored, emphasizing the influence of enrichment with organic matter and nutrients in benthic communities and plankton.

According to Bilkovic et al. (2005), as human populations and coastal development increase, pressures on the aquatic resources will multiply, so that maintaining the desired benefits derived from aquatic systems will require an informed management of anthropogenic impacts. Efficiency in decision making will therefore require a distillation of complex interactions and data down to a few information-rich metrics that can then provide guidance to the entities having the authority over environmental management.

Although the appropriate legislation of estuarine and coastal systems requires the use of key biological taxa (e.g., phytoplankton, benthos, algae, phanerogams, and fish) together with physicochemical entities (including pollutants), only a few methodologies have joint all of these indicators in a single environmental assessment tool (Borja et al. 2009). To that end, the approach employed in this work - it involving a combination of metrics from both phytoplanktonic and benthic communities - has enabled a correct assessment of the biotic integrity of the freshwater tidal zone of the Río de la Plata. In this regard, we wish to emphasize the need to promote further research on the freshwater zones of estuaries since the study of those regions requires a different approach due to their position between limnology and oceanography.

\section{Conclusion}

The multimetric index developed in this study combined metrics related to phytoplankton assemblage (cyanobacterial density and total density) with other metrics linked to benthic diatoms and invertebrates (the percentages of most tolerant diatoms and of Tanaidacea). This index, developed for the Río de la Plata estuary, reflects changes in the coast stemming from anthropogenic stressors, despite the marked inherent physical-chemical variability observed within the study area. The IBIRP is composed of metrics, each one being a useful environmental indicator for contributing to an assessment of the ecological status (eutrophication, pollution, and habitat quality) of the site being monitored. The metrics that were chosen to compose the IBIRP provide considerable insight into the integrity of the biotic status of 
the region with respect to both time and space. This index constitutes an approach capable of reflecting the anthropogenic impacts produced along the coast of the Río de la Plata, with the inherent flexibility of being amenable to modifications aimed at an ultimate validation for other estuaries of similar characteristics elsewhere.

Acknowledgments The authors would like to thank Jorge L. Donadelli for his assistance in chemical analysis and to Lic. J. Cochero for his assistance in the field and laboratory. We also wish to thank the assistance of the librarian Ricardo Albino. This study was supported by the projects ANPCyT, PICT 32077, and CONICET-PIP Res. 1556. The authors also wish to thank Dr. Donald F. Haggerty, a retired career investigator and native English speaker, for editing the final version of the manuscript. Finally, we would like to express our thanks to the anonymous reviewers for improvements in this manuscript. This is Instituto de Limnología "Dr. R. A. Ringuelet" scientific contribution no. 906.

\section{References}

AA-AGOSBA-ILPLA-SHN. 1997. Calidad de las Aguas de la Franja Costera Sur del Río de la Plata (San Fernando- Magdalena). Buenos Aires: Consejo Permanente para el Monitoreo de la Calidad de las Aguas de la Franja Costera Sur del Río de la Plata.

Adams, S.M. 2005. Using multiple response bioindicators to assess the health of estuarine ecosystems: An operational framework. In Estuarine indicators, ed. S.A. Bortone. Washington: CRC.

Barbour, M.T., J. Gerritsen, B.D. Snyder, and J.B. Stribling. 1999. Rapid bioassessment protocols for use in streams and wadeable rivers: Periphyton, benthic macroinvertebrates and fish. EPA 841-B-99-002. Washington: US Environmental Protection Agency, Office of Water.

Bilkovic, D.M., C.H. Hershner, M.R. Berman, K.J. Havens, and D.M. Stanhope. 2005. Evaluating nearshore communities as indicators of ecosystem health. In Estuarine indicators, ed. S.A. Bortone. Washington: CRC.

Böhmer, J., C. Rawer-Jost, and A. Zenker. 2004. Multimetric assessment of data provided by water managers from Germany: Assessment of several different types of stressors with macrozoobenthos communities. Hydrobiologia 516: 215-228.

Borja, A., and D.M. Dauer. 2008. Assessing the environmental quality status in estuarine and coastal systems: Comparing methodologies and indices. Ecological Indicators 8: 331-337.

Borja, A., J. Franco, and I. Muxika. 2004. The Biotic Indices and the Water Framework Directive: The required consensus in the new benthic monitoring tools. Marine Pollution Bulletin 48: 405-408.

Borja, A., J. Bald, M.J. Belzunce, J. Franco, J.M. Garmendia, I. Muxika, M. Revilla, G. Rodríguez, O. Solaun, I. Tueros, A. Uriarte, V. Valencia, I. Adarraga, F. Aguirrezabalaga, I. Cruz, A. Laza, M.A. Marquiegui, J. Martínez, E. Orive, J.M ${ }^{a}$ Ruiz, S. Seoane, J.C. Sola, and A. Manzanos. 2007. Red de seguimiento del estado ecológico de las aguas de transición y costeras de la Comunidad Autónoma del País Vasco. Report of AZTI-Tecnalia for Water Directorate, Department of Environment and Land Action. Basque Government.

Borja, A., J. Bald, J. Franco, J. Larreta, I. Muxika, M. Revilla, J.G. Rodríguez, O. Solaun, A. Uriarte, and V. Valenci. 2009. Using multiple ecosystem components, in assessing ecological status in Spanish (Basque Country) Atlantic marine waters. Marine Pollution Bulletin 59: 54-64.

Borja, A., M. Elliott, J. Carstense, A.S. Heiskanen, and W. van de Bund. 2010. Marine management-towards an integrated implementation of the European Marine Strategy Framework and the Water Framework Directives. Marine Pollution Bulletin 60: 2175-2186.

Bricker, S.B., C.G. Clement, D.E. Pirhalla, S.P. Orlando, and D.R.G. Farrow. 1999. National estuarine eutrophication assessment: Effects of nutrient enrichment in the nation's estuaries. Silver Spring, MD: NOAA, National Ocean Service, Special Projects Office and the National Centers for Coastal Ocean Science.

César, I., C.S. Ocón, A.C. Paggi, A. Rodrigues Capítulo, F. Spaccesi, M. Tangorra, and M. Tassara. 2000. Diversidad de invertebrados bentónicos del Río de la Plata. Biología Acuática 19: 27-64.

Clesceri, L.S., A.E. Greenberg, and A.D. Eaton. 1998. Standard methods for the examination of water and wastewater. Washington: American Public Health Association (APHA).

Codd, G.A., J. Lindsay, F.M. Young, L.F. Morrison, and J.S. Metcalf. 2005. Harmful cyanobacteria. In Harmful Cyanobacteria. Aquatic ecology series, vol. 3, ed. J. Huisman, H.C.P. Matthijs, and P.M. Visser. Dordrecht: Springer.

Dauer, D.M. 1993. Biological criteria, environmental health and estuarine macrobenthic community structure. Marine Pollution Bulletin 26: 249-257.

De León, L., and J.S. Yunes. 2001. First report of a microcystincontaining bloom of the cyanobacterium Microcystis aeruginosa in the La Plata River, South America. Environmental Toxicology 16: $110-112$.

Descy, J.P., and M. Coste. 1990. Utilisation des diatome' es benthiques pour l' evaluation de la qualite' des aux courantes, Contrat CEE B-71-23, Rapport final, Cemagref.

Ferreira, A.C., A. Rodrigues Capítulo and E.S. Ambrosio. 2008. "Respuestas poblacionales de Sinelobus stanfordi (Crustacea: Tanaidacea) a la perturbación ambiental en un sistema estuarial templado (FCS-Río de la Plata)", 29. IV Congreso Argentino de Limnología.

Ferreira, J.G., J.H. Andersen, A. Borja, S.B. Bricker, J. Camp, M. Cardoso da Silva, E. Garcés, A.S. Heiskanen, G. Humborg, L. Ignatiades, C. Lancelot, A. Menesguen, P. Tett, N. Hoepffner, and U. Claussen. 2011. Overview of eutrophication indicators to assess environmental status within the European Marine Strategy Framework Directive. Estuarine, Coastal and Shelf Science 93: $117-131$.

FREPLATA. 2005. Análisis Diagnóstico Transfronterizo del Río de la Plata y su Frente Marítimo. Proyecto "Protección Ambiental del Río de la Plata y su Frente Marítimo: Prevención y Control de la Contaminación y Restauración de Hábitats". Documento Técnico. Proyecto PNUD/GEF RLA/99/G31. Montevideo, Uruguay.

Gómez, N., and D. Bauer. 2000. Diversidad fitoplanctónica en la Franja Costera Sur del Río de la Plata. Biología Acuática 19: 7 26.

Gómez, N., and M. Licursi. 2001. The Pampean Diatom Index (IDP) for assessment of rivers and streams in Argentina. Aquatic Ecology 35: 173-181.

Gómez, N., P.R. Hualde, M. Licursi, and D. Bauer. 2004. Spring phytoplankton of Río de la Plata: A temperate estuary of South America. Estuarine, Coastal and Shelf Science 61: 301-309.

Gómez, N., M. Licursi, and J. Cochero. 2009. Seasonal and spatial distribution of the microbenthic communities of the Río de la Plata estuary (Argentina) and possible environmental controls. Marine Pollution Bulletin 58: 878-887.

Guerra-García, J.M., and J.C. García-Gómez. 2004. Crustacean assemblages and sediment pollution in an exceptional case study: A harbour with two opposing entrances. Crustaceana 77: 353-370.

Guerrero, M.A., M.E. Acha, M.B. Framinan, and C. Lasta. 1997. Physical oceanography of the Río de la Plata Estuary. Continental Shelf Research 17: 727-742.

Guidetti, P., M. Modena, G. La-Mesa, and M. Vacchi. 2000. Composition, abundance and stratification of macrobenthos in the marine 
area impacted by tar aggregates derived from the haven oil spill (Ligurian Sea, Italy). Marine Pollution Bulletin 40: 1161-1166.

Hering, D., C.K. Feld, O. Moog, and T. Ofenböck. 2006. Cook book for the development of a Multimetrix Index for biological condition of aquatic ecosystems: Experiences from the European AQEM and STAR projects and related initiatives. Hydrobiologia 566: 311-324.

Jordan, S.J., and P.A. Vaas. 2000. An index of ecosystem integrity for Northern Chesapeake Bay. Environmental Science and Policy 3: 59-88.

Kane, D.D., S.I. Gordon, M. Munawar, M.N. Charlton, and D.A. Culver. 2009. The Planktonic Index of Biotic Integrity (P-IBI): An approach for assessing lake ecosystem health. Ecological Indicators 9: 1234-1247.

Karr, J.R., and E.W. Chu. 1999. Restoring life in running waters: Better biological monitoring. Washington: Island Press.

Karr, J.R., and D.R. Dudley. 1981. Ecological perspective on water quality goals. Environmental Management 5: 55-68.

Kaufmann, P.R., P. Levine, E.G. Robison, C. Seeliger, and D. Peck. 1999. Quantifying physical habitat in wadeable streams. EPA/ 620/R-99/003. Washington: US Environmental Protection Agency, Office of Research and Development.

Lacouture, R.V., J.M. Johnson, C. Buchanan, and H.G. Marshall. 2006. Phytoplankton index of biotic integrity for Chesapeake Bay and its tidal estuaries. Estuaries and Coasts 29: 598-616.

Lahitte, H., J. Hurrel, M.J. Belgrano, L.S. Jankowski, and K. Mehltreter. 2004. Plantas de la Costa. Buenos Aires: Literature of Latin America (L.O.L.A.).

Lampman, G., N.F. Caraco, and J.J. Cole. 1999. Spatial and temporal patterns of nutrient concentration and export in the tidal Hudson River. Estuaries 22: 285-296.

Licursi, M., N. Gómez, and J. Donadelli. 2010. Ecological optima and tolerances of coastal benthic diatoms in the freshwater-mixohaline zone of the Río de la Plata estuary. Marine Ecology Progress Series 418: 105-117.

Lionard, M., K. Muylaert, A. Hanoutti, T. Maris, M. Tackx, and W. Vyverman. 2008. Inter-annual variability in phytoplankton summer blooms in the freshwater tidal reaches of the Schelde estuary (Belgium). Estuarine, Coastal and Shelf Science 79: 694-700.

Lund, J.W.G., C. Kipling, and E.D. Le Cren. 1958. The inverted microscope method of estimating algal numbers and the statistical basis of estimations by counting. Hydrobiologia 11: 143-170.

Mackereth, F.J., F.J.H. Heron, and J.F. Talling. 1978. Water analysis: Some revised methods for limnologists. Scientific publication no. 36. Freshwater Biological Association.

Margalef, R. 1983. Limnología. Barcelona: Omega.

Merrit, R.W., and K.W. Cummins. 1996. An introduction to the aquatic insects of North America. Dubuque: Kendall/Hunt.

Mianzan, H., C. Lasta, E. Acha, R. Guerrero, G. Macchi, and C. Bremec. 2001. The Río de la Plata Estuary, Argentina-Uruguay. In Coastal marine ecosystems of Latin America. Ecological studies, ed. U. Seeliger and B. Kjerfve. Berlin: Springer.

Muniz, P., N. Venturini, A.M.S. Pires-Vani, L.R. Tommasi, and A. Borja. 2005. Testing the applicability of a Marine Biotic Index (AMBI) to ssessing the ecological quality of soft-bottom benthic communities, in the South America Atlantic región. Marine Pollution Bulletin 50: 624-637.
Nagy, G.J., M. Gómez-Erache, C.H. López, and A.C. Perdomo. 2002. Distribution patterns of nutrients and symptoms of eutrophication in the Río de la Plata estuarine system. Hydrobiologia 475(476): $125-139$.

Paerl, H.W., J. Dyble, P.H. Moinsander, R.T. Noble, M.F. Piehler, J.L. Pinckney, F.S. Steppe, L. Twomey, and L.M. Valdes. 2003. Microbial indicators of aquatic ecosystem change: Current applications to eutrophication studies. Microbiology Ecology 46: 233246.

Pearson, T.H., and R. Rosenberg. 1978. Macrobenthic succession in relation to organic enrichment and pollution of the marine environment. Oceanography Marine Biology Annual Review 16: 229 311.

Pielou, E.C. 1969. An introduction to mathematical ecology. New York: Wiley-Interscience.

Pla, L.E. 1986. Análisis Multivariado: Método de Componentes Principales. Washington: The General Secretariat of the Organization of American States.

Rodrigues Capítulo, A., I. César, M. Tassara, A.C. Paggi, and M. Remes Lenicov. 1997. Zoobentos. In Calidad de las Aguas de la Franja Costera Sur del Río de la Plata. San FernandoMagdalena, 131-141. Buenos Aires: Consejo Permanente para el monitoreo de la calidad de las aguas de la Franja Costera Sur del Río de la Plata.

Rodrigues Capítulo, A., M. Tangorra, and C.S. Ocón. 2001. Use of benthic macroinvertebrate to assess the ecological status of Pampean rivers (Argentine). Aquatic Ecology 35: 109-119.

Schuchardt, B., and M. Schirmer. 1991. Phytoplankton maxima in the tidal freshwater reaches of two coastal plain estuaries. Estuarine, Coastal and Shelf Science 32: 187-206.

Shannon, C.E., and W. Weaver. 1949. A mathematical theory of communication. London: University Illinois Press.

Singh, K.P., A. Malik, D. Mohan, and S. Sinha. 2004. Multivariate statistical techniques for the evaluation of spatial and temporal variations in water quality of Gomti River (India) - a case study. Water Research 38: 3980-3992.

Sloane, D., and S.P. Morgan. 1996. An introduction to categorical data analysis. Annual Review of Sociology 22: 351-375.

Snoeijs, P. 1999. Applied diatom studies in estuaries and shallow coastal. In The diatoms: Applications for the environmental and earth sciences, ed. F. Stoermer and J.P. Smol, 298-333. Cambridge: Cambridge University Press.

Stoddard, J.L., A.T. Herlihy, D.V. Peck, R.M. Hughes, R.T. Whittier, and E. Tarquinio. 2008. A process for creating multimetric indices for large-scale aquatic surveys. Journal of the North American Benthological Society 27: 878-891.

Taberner, R. 1983. Hallazgo de un tanaidáceo del género Kalliapseudes en la costa bonaerense del Río de La Plata. Neotropica 29: 2.

Urien, C.M. 1972. Río de la Plata estuary environments. In Environmental Framework of Coastal Plain Estuaries, Memoir 133, ed. B.W. Nelson, 213-234. Boulder: The Geological Society of America.

USEPA. 1998. Lake and reservoir bioassessment and biocriteria: Technical guidance document. EPA 841-B-98-007.

USEPA. 2006. Voluntary estuary monitoring manual. EPA-842-B-06003.

Zar, J.H. 1996. Biostatistical analysis. New Jersey: Prentice-Hall. 